\title{
Treatment of stabilized landfill leachate in an integrated adsorption-fine-ultrafiltration system
}

\author{
D. Kulikowska ${ }^{1} \cdot$ M. Zielińska ${ }^{1} \cdot$ K. Konopka ${ }^{1}$
}

Received: 10 October 2017 / Revised: 5 April 2018 / Accepted: 5 May 2018 / Published online: 15 May 2018

(c) The Author(s) 2018

\begin{abstract}
This study investigated the feasibility of using an adsorption-fine-ultrafiltration system for removing organics from stabilized landfill leachate. For adsorption, Norit SX2 powdered activated carbon was used; the fine-ultrafiltration system was equipped with a ceramic membrane. Due to low organics removal efficiency in fine-ultrafiltration alone (series 1) (46.5\% of chemical oxygen demand, $22.1 \%$ of dissolved organic carbon), two doses of activated carbon were used for adsorption before fine-ultrafiltration: $0.2 \mathrm{~g} / \mathrm{L}$ (series 2) and $1 \mathrm{~g} / \mathrm{L}$ (series 3). Although organics removal efficiency at both doses of Norit SX2 differed (12.9 and 34.5\% of chemical oxygen demand, 12.2 and 54.7\% of dissolved organic carbon, at 0.2 and $1 \mathrm{~g} / \mathrm{L}$, respectively), permeate quality did not differ substantially. Although the use of Norit SX2 improved permeate quality in comparison with fine-ultrafiltration alone $(220 \mathrm{mg} / \mathrm{L}$ in series 2 and $209 \mathrm{mg} / \mathrm{L}$ in series $3 \mathrm{vs.} 842 \mathrm{mg} / \mathrm{L}$ in series 1$)$, its particles blocked the membrane and lowered the permeate flux even at the lower dose. In the series with adsorption, permeate flux was about 10 times lower than during fine-ultrafiltration alone. This indicates that, in fine-ultrafiltration preceded by adsorption on activated carbon, it is reasonable to use the lower dose of Norit SX2 because the efficiency of treatment is similar to that at the higher dose, but the reduction in permeate flux is somewhat less. These results indicate that the possibility of using adsorption-fine-ultrafiltration in the practice of leachate treatment is limited because of blocking membrane pores with particles of activated carbon.
\end{abstract}

Keywords Activated carbon $\cdot$ Fouling $\cdot$ Membrane technique $\cdot$ Organic compounds

\section{Introduction}

Although leachate from old landfills usually contains much lower concentrations of organic pollutants than leachate from young landfills, its treatment remains a problem due to low biodegradability of organics. As refractory organics predominate in stabilized leachate, biological methods are not effective for their removal. These substances can be removed with physicochemical treatments, which can also be used to polish biologically treated leachate. Among these treatments, coagulation, advanced oxidation, including ozonation and Fenton reaction, adsorption and membrane

Editorial responsibility: Josef Trögl

M. Zielińska

magdalena.zielinska@uwm.edu.pl

1 Department of Environmental Biotechnology, University of Warmia and Mazury in Olsztyn, 45G Sloneczna St, 10-907 Olsztyn, Poland systems (Sanjay et al. 2013; Assou et al. 2016; Kamaruddin et al. 2017) can be used. Some authors used the combination of different physicochemical methods such as coagulation-adsorption (Gandhimathi et al. 2013; Chaouki et al. 2017).

Among the various membrane technologies, reverse osmosis (RO) and nanofiltration (NF) have been found to be efficient in removal of organic contaminants from leachate. RO can remove suspended and colloidal materials, dissolved solids and heavy metals, with an efficiency of 98-99\% for organic and inorganic contaminants (Renou et al. 2008). Despite its more open membrane structure, NF can also remove recalcitrant organic compounds and heavy metals (Chaudhari and Murthy 2010). This method removes particles with a molecular weight $(\mathrm{MW})>300 \mathrm{Da}$ and inorganic substances via electrostatic interactions. The major drawback to RO and NF is that they consume high amount of energy, and the rate of consumption increases with the feed pressure. 
Therefore, a low-pressure membrane technique like ultrafiltration (UF) is used in separation and purification because of its high efficiency and lower energy consumption, which lowers treatment costs. The separation efficiency of this technique mainly depends on the size of particles of the separated compounds and the molecular weight cutoff of the membrane. UF is effective in eliminating macromolecules and particles, but is characterized by low rejection of organics with low MW. Therefore, for obtaining higher efficiency of contaminant removal, integrated systems, i.e., adsorption-UF, are used for treatment of water/wastewater that contains pollutants with different MWs. For example, an activated carbon adsorption-UF effectively removed organic substances from landfill leachate (Dolar et al. 2016). In such systems, the role of activated carbon suspended in the feed solution is to adsorb low-MW organic compounds that cannot be separated by UF alone. Campinas and Rosa (2010) showed that powdered activated carbon (PAC)-UF is effective for removing cyanobacteria and their toxins during water treatment. In this kind of system, PAC efficiently removes microcystin and competes with the membrane for natural organic matter (NOM), which reduces the adsorption of NOM on/in membrane structure, whereas UF retains cyanobacteria.

Although the basic idea of combining adsorption with UF is to obtain high rejection of contaminants, adding the adsorption step before membrane filtration can also lower the membrane fouling. Efficient fouling control is necessary for reducing the frequency of cleaning and making the treatment processes economically favorable.

Although some authors have found that combining membrane filtration with adsorption on PAC alleviates membrane fouling, other authors have found contradictory results. PAC addition can reduce membrane fouling by preventing adsorption of organics on the membrane surface, which improves permeate flux, lengthens filtration runs and prolongs membrane life (Damayanti et al. 2011). However, Mozia et al. (2005) and Zhao et al. (2005) found that PAC reduced or did not reduce the flux, depending on membrane hydrophobicity. Not only are these studies contradictory, but they investigated the effect of PAC on UF in water/wastewater treatment or the effect of the size of adsorbate molecules on the efficiency of sorption from water solutions containing compounds of low MW (like phenol) or of high MW (like humic acids). Although these studies are very useful for explanation of process mechanisms, they cannot be transferred directly into practical applications. This is because landfill leachate contains organic compounds of low, medium and high MW, and high concentrations of inorganic compounds. This mixture of organic compounds determines the efficiency of sorption, whereas inorganic compounds may cause membrane scaling, thus affecting the process of separation. Therefore, to evaluate the proposed technology of adsorption-membrane filtration, real landfill leachate was used in the present study. Although adsorption is an effective method for leachate treatment, the high consumption of adsorbent is the main problem. To limit its consumption, it is important to conduct the process at the dose at which relatively low consumption of adsorbent yields high process efficiency. Therefore, in this study, adsorption at extremely low activated carbon dose was combined with fine-UF. The membrane used in this study is defined as a fine-UF membrane because of a more dense separation layer than that of ordinary UF membranes, which ensures a lower cutoff of the membrane. The research was carried out in 2015 in Olsztyn, Poland.

\section{Materials and methods}

\section{Leachate}

The leachate was taken from a 14-year-old municipal landfill in northeastern Poland. This landfill contains only municipal wastes (including solid waste, non-composted fraction of municipal waste, screenings, grit, stabilized sewage sludge), without liquid, fecal, hazardous, radioactive and toxic wastes. In this landfill, leachate flows through a drain system to a retention tank, from which it is distributed on the landfill area or periodically transported to a municipal wastewater treatment facility. For this study, leachate was sampled from the retention tank, delivered to the laboratory and stored at $4{ }^{\circ} \mathrm{C}$. The composition of the leachate is shown in Table 1.

Table 1 Characteristics of raw landfill leachate (average $\pm \mathrm{SD}, n=4$ )

\begin{tabular}{lll}
\hline Characteristic & Unit & Value \\
\hline $\mathrm{pH}$ & - & $8.36 \pm 0.04$ \\
$\mathrm{COD}$ & $\mathrm{mg} / \mathrm{L}$ & $1560 \pm 102$ \\
$\mathrm{BOD}_{5}$ & $\mathrm{mg} / \mathrm{L}$ & $168 \pm 8$ \\
BOD $_{5} / \mathrm{COD}$ & - & 0.11 \\
Dissolved organic carbon (DOC) & $\mathrm{mg} / \mathrm{L}$ & $382 \pm 21$ \\
Inorganic carbon (IC) & $\mathrm{mg} / \mathrm{L}$ & $1377 \pm 82$ \\
Kjeldahl nitrogen & $\mathrm{mg} / \mathrm{L}$ & $495 \pm 32$ \\
Ammonia nitrogen & $\mathrm{mg} / \mathrm{L}$ & $464 \pm 28$ \\
Total phosphorus & $\mathrm{mg} / \mathrm{L}$ & $48.3 \pm 6.4$ \\
Total dissolved solids & $\mathrm{mg} / \mathrm{L}$ & $7689 \pm 548$ \\
Organic dissolved solids & $\mathrm{mg} / \mathrm{L}$ & $1400 \pm 185$ \\
Inorganic dissolved solids & $\mathrm{mg} / \mathrm{L}$ & $6289 \pm 489$ \\
UV $_{254}$ & $\mathrm{~cm}^{-1}$ & $2.75 \pm 0.21$ \\
UV $_{410}$ & $\mathrm{~cm}^{-1}$ & $1.51 \pm 0.06$ \\
\hline
\end{tabular}




\section{Membrane installation}

The installation consisted of a feed tank (10 L), a high pressure pump, an external membrane module, a flowmeter, a heat exchanger, a pre-filter (1-mm mesh), pressure gauges on inlet and outlet of the module, a pipe for recirculation of the retentate to the feed tank and a pipe to collect the permeate from the installation (Fig. 1). In the INSIDE Céram ${ }^{\mathrm{TM}}$ asymmetric tubular membrane (Tami Industries), both a support and an active layer are made of $\mathrm{TiO}_{2}$. The characteristics of the membrane are as follows: length, $300 \mathrm{~mm}$; external diameter, $25 \mathrm{~mm} ; 23$ channels inside, hydraulic diameter of each channel, $3.5 \mathrm{~mm}$; total filtration area, $0.1 \mathrm{~m}^{2}$. A membrane for fine-UF with cutoff of $5 \mathrm{kDa}$ was used. The installation worked in cross-flow mode. The installation was operated at a constant pressure of $0.8 \mathrm{MPa}$.

Leachate from stabilized landfills contains refractory compounds, including humic and fulvic acids. Although these substances are characterized by a relatively large MW, the use of fine-UF alone was insufficient for their removal. Therefore, in this study, fine-UF was preceded by adsorption on Norit SX2 PAC.

\section{Adsorption with PAC}

The present study used Norit SX2, a commercially produced PAC, of which the main characteristics are as follows: $\mathrm{pH}$ ca. 7.0; specific area, $900 \mathrm{~m}^{2} / \mathrm{g}$; iodine number, $800 \mathrm{mg} / \mathrm{g}$; methylene number, $150 \mathrm{mg} / \mathrm{g}$; moisture, $10 \%$; ash, $5 \%$. Characteristic diameters of the PAC particles were: $d_{10}=3 \mu \mathrm{m}$, $d_{50}=20 \mu \mathrm{m}$, and $d_{90}=110 \mu \mathrm{m}$.

The kinetic adsorption experiment was carried out in six 2-L beakers stirred with magnetic stirrers, in which Norit SX2 was tested in the following doses: $0.2,0.5,1.0,2.0$, 3.0 and $5.0 \mathrm{~g} / \mathrm{L}$. The experiment was conducted at real $\mathrm{pH}$

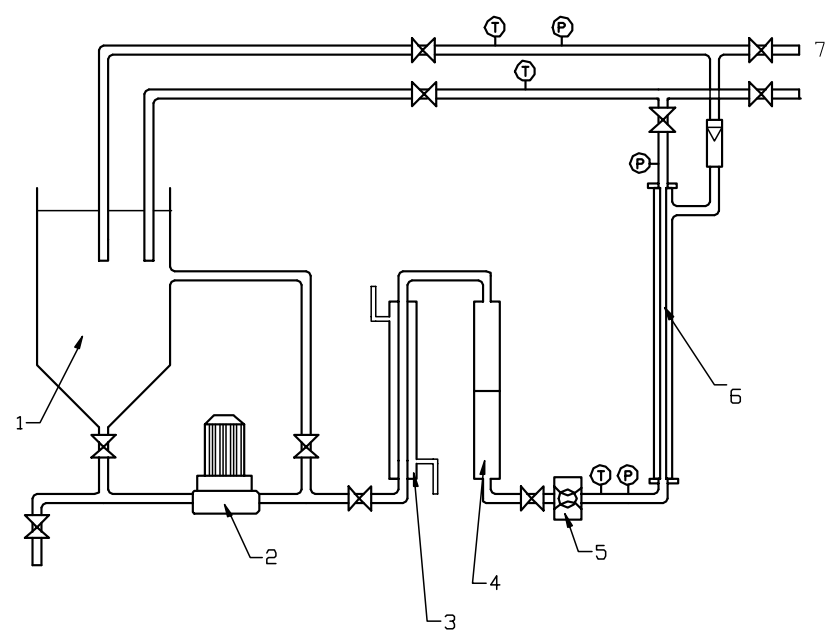

Fig. 1 Schematic of the membrane installation. 1 process tank, 2 pump, 3 heat exchanger, 4 prefilter, 5 flow control, 6 membrane module, 7 permeate sampling point, $T$ thermometer, $P$ manometer of the leachate. A residence time was sufficient to allow the adsorption of the contaminants present in the leachate. After adsorption, the concentrations of COD and DOC, and $\mathrm{UV}_{254}$ and $\mathrm{UV}_{410}$ absorption were determined. On the basis of these results, two doses of Norit SX2 were chosen for further study $(0.2$ and $1.0 \mathrm{~g} / \mathrm{L})$.

\section{Experimental setup}

Before adding leachate to the fine-UF installation, selected doses of PAC were mixed with the leachate for $0.5 \mathrm{~h}$ (the time in which equilibrium was obtained, based on kinetics data). This suspension, after 0.5 -h sedimentation, was then fed to the fine-UF unit. Three experimental series were conducted: series 1 (control)-fine-UF alone; series 2adsorption with $0.2 \mathrm{~g} / \mathrm{L}$ of PAC followed by fine-UF; series 3 -adsorption with $1.0 \mathrm{~g} / \mathrm{L}$ of PAC followed by fine-UF.

\section{Membrane filtration}

After circulation of distilled water in the membrane module for $20 \mathrm{~min}$, the average flux of distilled water $\left(J_{\mathrm{W}}\right)$ was measured and the result was about $640 \mathrm{~L} /\left(\mathrm{m}^{2} \mathrm{~h}\right)$. After that, filtrations of leachate were conducted at $21^{\circ} \mathrm{C}$ and with a velocity of feed flow of $7-11 \mathrm{~L} / \mathrm{min}$. During these filtrations, membrane productivity in time was determined: the times of receiving each $0.5 \mathrm{~L}$ of permeate was measured. These permeation tests were conducted up to the membrane clogging when the flow of the permeate stopped. Then, the membranes were washed. The permeation tests in each series were conducted in duplicate.

In the equations, the following abbreviations were used: $A$-area of membrane $\left(\mathrm{m}^{2}\right), C_{\mathrm{F}}$-pollutant concentration in the feed $(\mathrm{mg} / \mathrm{L}), C_{\mathrm{P}}-$ pollutant concentration in the permeate $(\mathrm{mg} / \mathrm{L}), C_{\mathrm{R}}$ - pollutant concentration in the retentate $(\mathrm{mg} / \mathrm{L}), t$ - time for receiving $0.5 \mathrm{~L}$ of permeate $(\mathrm{h})$, TMP - transmembrane pressure (MPa), $V_{\mathrm{F}}$-feed volume $(\mathrm{L}), V_{\mathrm{P}}$-permeate volume $(\mathrm{L}), V_{\mathrm{R}}$-retentate volume (L).

The permeate flux $\left(J_{\mathrm{V}}\right.$, Eq. 1$)$ is calculated as follows:

$J_{\mathrm{V}}=\frac{V_{\mathrm{P}}}{t \cdot A} \quad\left(\mathrm{~L} /\left(\mathrm{m}^{2} \mathrm{~h}\right)\right)$

The efficiency of filtration was measured based on the recovery value that is the portion of the feed which is transported through the membrane ( $Y$, Eq. 2), the volume concentration factor (VCF, Eq. 3) and total membrane resistance $\left(R_{\mathrm{m}}\right.$, Eq. 4$)$ :

$Y=\frac{V_{\mathrm{P}}}{V_{\mathrm{F}}} \times 100$

$\mathrm{VCF}=\frac{V_{\mathrm{F}}}{V_{\mathrm{F}}-V_{\mathrm{P}}}$ 
$R_{\mathrm{m}}=\frac{\mathrm{TMP}}{J_{\mathrm{V}}} \quad((\mathrm{MPa} \mathrm{s}) / \mathrm{m})$

The percentage of rejection ( $R$, Eq. 5) showed the separation properties of the membrane:

$R=\left(1-\frac{C_{\mathrm{P}}}{C_{\mathrm{F}}}\right) \times 100$

The adsorption capacity (Ads) is calculated with Eq. 6:

Ads $=\left(1-\frac{C_{\mathrm{R}} V_{\mathrm{R}}+C_{\mathrm{P}} V_{\mathrm{P}}}{C_{\mathrm{F}} V_{\mathrm{F}}}\right) \times 100$

To determine the fouling intensity, the normalized permeate flux $(\alpha)$ was calculated by dividing the $J_{\mathrm{V}}$ by the $J_{\mathrm{W}}$.

\section{Analytical methods}

In the raw leachate, $\mathrm{pH}$ (HI $8818 \mathrm{pH}$ meter), COD (Standard Methods 1992), BOD (DIN EN 1899-1/EN 1899-2 official EPA method using OxiTop WTW Wissenschaftlich-Technische Werksträtten GmbH, D-82326 Weilheim, Germany), Kjeldahl and ammonia nitrogen and total phosphorus (Standard Methods 1992), total dissolved solids and volatile dissolved solids (Hermanowicz et al. 1999) were determined. After filtration of leachate samples (a $0.45-\mu \mathrm{m}$ filter), dissolved organic carbon (DOC) and inorganic carbon (IC) (Shimadzu Liquid TOC- $V_{\text {CSN }}$ analyzer), UV optical density at $254 \mathrm{~nm}$ (for aromatic and unsaturated organic compounds, Chiang et al. 2006) and at $410 \mathrm{~nm}$ (for color, with a Cary UV/Visible spectrophotometer in 1-cm path length quartz cuvettes) were measured. In the treated leachate, COD, DOC, IC, $\mathrm{UV}_{254}$ and $\mathrm{UV}_{410}$ were measured.

\section{Results and discussion}

\section{Characteristics of landfill leachate}

The high $\mathrm{pH}(8.36 \pm 0.04)$, the low concentrations of organic substances $\left(1560 \pm 102 \mathrm{mg} \mathrm{COD} / \mathrm{L}\right.$ and $\left.168 \pm 8 \mathrm{mg} \mathrm{BOD}_{5} / \mathrm{L}\right)$ and the low $\mathrm{BOD}_{5} / \mathrm{COD}$ ratio $(0.11)$ (Table 1$)$ confirmed that the leachate came from an old landfill. A low organics concentration in leachate from an old landfill is a typical phenomenon. For example, Bernardo-Bricker et al. (2014) showed that, in leachate from municipal solid waste landfill in north Palm Beach County, Florida, that has been in operation for greater than 20 years, $\mathrm{COD}, \mathrm{BOD}_{5}$ and $\mathrm{BOD}_{5} / \mathrm{COD}$ were $1092-2184,38-151 \mathrm{mg} / \mathrm{L}$ and $0.035-0.069$, respectively. Cortez et al. (2010a) reported that, in leachate from an old landfill located in Portugal, COD and $\mathrm{BOD}_{5}$ were as low as 743 and $10 \mathrm{mg} / \mathrm{L}$. Similarly, Lee et al. (2010) found that, in old leachate, the mean concentrations of $\mathrm{COD}, \mathrm{BOD}_{5}$ and
DOC were 875, 195 and $290 \mathrm{mg} / \mathrm{L}$, respectively. However, some authors have indicated that the concentration of COD may be high even in leachate from old landfill. The landfill leachate in Vilappilsala was characterized by $24,000 \mathrm{mg}$ $\mathrm{COD} / \mathrm{L}, 7500 \mathrm{mg} \mathrm{BOD} / \mathrm{L}$ and the $\mathrm{BOD}_{5} / \mathrm{COD}$ ratio of 0.3 (Sivan and Latha 2013).

$\mathrm{UV}_{254}$ absorption is an indicator of the concentration of humic substances and indicates that conjugated double bonds are present in aromatic and unsaturated organic substances (Chiang et al. 2006). In the present study, $\mathrm{UV}_{254}$ was $2.75 \pm 0.21 \mathrm{~cm}^{-1}$ in the raw leachate. According to Rivas et al. (2006), $\mathrm{UV}_{254}$ was $40 \mathrm{~cm}^{-1}$ in leachate from an Italian landfill; this is almost 15 times higher than in this study. However, other authors have found low values of $\mathrm{UV}_{254}$ that are similar to that in the present study. For example, Cortez et al. (2010b) reported that $U_{254}$ in leachate from a landfill in Portugal was $2.614 \mathrm{~cm}^{-1}$. A substantially lower value of $\mathrm{UV}_{254}, 0.312 \mathrm{~cm}^{-1}$, was found by Leszczyński et al. (2016) in leachate from a landfill in Poland.

In this study, the concentration of total dissolved solids (TDS) was $7689 \pm 548 \mathrm{mg} / \mathrm{L}$, which was similar to the lowest concentration of TDS found by Bernardo-Bricker et al. (2014). They found that the concentration of TDS ranged from 7057 to $19,066 \mathrm{mg} / \mathrm{L}$. The concentrations of Kjeldahl and ammonia nitrogen in the leachate used in this study were relatively high, $495 \pm 32$ and $464 \pm 28 \mathrm{mg} / \mathrm{L}$, respectively. Also, the total $\mathrm{P}$ concentration was relatively high $(48.3 \pm 6.4 \mathrm{mg} / \mathrm{L})$. Cortez et al. (2010a) noted a higher concentration of ammonia $(714.3 \mathrm{mg} / \mathrm{L})$ and a much lower concentration of phosphates $(0.479 \mathrm{mg} / \mathrm{L})$ in stabilized leachate.

\section{Efficiency of landfill leachate treatment}

\section{Efficiency of removal of organic compounds with Norit SX2}

The previous investigations of landfill leachate of a similar composition revealed that PAC is more effective than granular activated carbon (GAC) at the same adsorption conditions. In the dose range of $2-3 \mathrm{~g} / \mathrm{L}$ for PAC and $2-10 \mathrm{~g} / \mathrm{L}$ for GAC, a dose increase by $1 \mathrm{~g} / \mathrm{L}$ resulted in the increase in the efficiency of COD removal by $19.1 \%$ (PAC) and by $4.0-4.3 \%$ (GAC) (Kulikowska et al. 2016). Furthermore, equilibrium was obtained within $30 \mathrm{~min}$ for PAC and $48 \mathrm{~h}$ for GAC. Therefore, in this study, for integrated adsorption-fine-UF system, PAC was used.

For determination of the range of doses at which process efficiency increases the most, the leachate was adsorbed with PAC at doses from 0.2 to $5 \mathrm{~g} / \mathrm{L}$ (Fig. 2). At lower doses $(<1 \mathrm{~g} / \mathrm{L})$, COD removal efficiency increased by $26.3 \%$ with a $1 \mathrm{~g} / \mathrm{L}$ increase in Norit SX2 (Fig. 2a), and DOC removal efficiency increased by $53.1 \%$ (Fig. 2b). At higher doses (1-5 g/L), smaller increases in adsorption efficiency were observed: COD removal efficiency increased by $10.5 \%$ with 


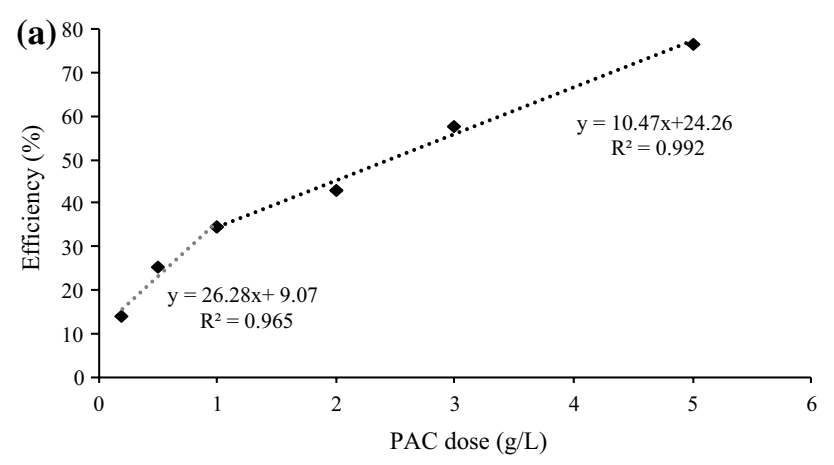

Table 2 Percent efficiency of PAC adsorption $\left(E_{\mathrm{S}}\right)$, removal by membrane $(R)$ and total efficiency of removal $\left(E_{\text {tot }}\right)$ for particular pollutants

\begin{tabular}{lllll}
\hline Parameter & & Series 1 & Series 2 & Series 3 \\
\hline COD & $E_{\mathrm{S}}$ & - & 12.9 & 34.5 \\
& $R$ & 46.5 & 83.9 & 79.7 \\
& $E_{\text {tot }}$ & 46.5 & 86.0 & 86.7 \\
$\mathrm{IC}$ & $E_{\mathrm{S}}$ & - & $-^{\mathrm{a}}$ & $-^{\mathrm{a}}$ \\
& $R$ & 20.7 & 33.8 & 44.3 \\
& $E_{\text {tot }}$ & 20.7 & 33.8 & 44.3 \\
$\mathrm{DOC}$ & $E_{\mathrm{S}}$ & - & 12.2 & 54.7 \\
& $R$ & 22.1 & 86.4 & 83.5 \\
$\mathrm{UV}$ & $E_{\text {tot }}$ & 22.1 & 88.1 & 92.5 \\
& $E_{\mathrm{S}}$ & - & 25.5 & 45.0 \\
& $R$ & 20.2 & 35.1 & 12.5 \\
$\mathrm{UV}_{410}$ & $E_{\text {tot }}$ & 20.2 & 51.7 & 51.9 \\
& $E_{\mathrm{S}}$ & - & 25.4 & 38.1 \\
& $R$ & 16.4 & 92.3 & 89.5 \\
& $E_{\text {tot }}$ & 16.4 & 94.3 & 93.5 \\
\hline
\end{tabular}

${ }^{\text {a }}$ During adsorption, IC was not removed

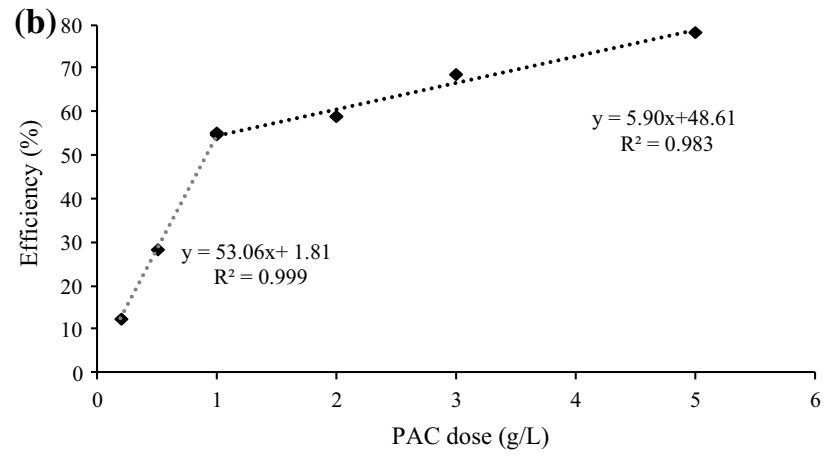

Fig. 2 Efficiency of COD (a) and DOC (b) removal with different PAC doses

an increase in Norit SX2 dose of $1 \mathrm{~g} / \mathrm{L}$, and DOC removal efficiency increased by $5.9 \%$. Due to the fact that the high utilization of carbon yielded a low increase in the efficiency of adsorption, these results indicate that doses above $1 \mathrm{~g} / \mathrm{L}$ are less efficient, which makes the process uneconomical.

Therefore, to study the efficiency of the removal of organic substances in the PAC-fine-UF system, two doses of PAC were used: $0.2 \mathrm{~g} / \mathrm{L}$ (series 2) and $1 \mathrm{~g} / \mathrm{L}$ (series 3 ). Although the lower dose gave only low process efficiency, adding PAC to leachate should improve hydraulic parameters of fine-UF. Theoretically, adding PAC to leachate before membrane filtration improves the permeate flux. This is because powdered adsorbent serves as a filter aid, and nonpolar carbon particles within a fouling layer makes it easily removable (Meier et al. 2002). In series 3, $1 \mathrm{~g} / \mathrm{L}$ of Norit SX2 was added to the leachate to remove as much as possible of the organic contaminants with a relatively low consumption of PAC.

\section{Fine-UF and PAC-fine-UF}

In fine-UF alone (series 1, control), the rejection coefficient $(R)$ for COD was $46.5 \%$, that of DOC was $22.1 \%$, and those of $\mathrm{UV}_{254}$ and $\mathrm{UV}_{410}$ were 20.2 and $16.4 \%$, respectively (Table 2). According to Bohdziewicz et al. (2001), 50\% of the organic substances from landfill leachate could be rejected by UF alone. In a study by Renou et al. (2009) with
UF membranes, the reduction of COD was from $38 \%$ (cutoff of $50 \mathrm{kDa}$ ) to $66 \%$ (cutoff of $1 \mathrm{kDa}$ ) from raw leachate.

The low efficiencies of rejection of DOC, humic substances and color were the reasons for the use of integrated systems incorporating adsorption by PAC and fine-UF. At a lower PAC dose $(0.2 \mathrm{~g} / \mathrm{L}), 12.9 \%$ of COD, $12.2 \%$ of DOC, $25.5 \%$ of humic substances (expressed as $\mathrm{UV}_{254}$ ) and $25.4 \%$ of color (expressed as $\mathrm{UV}_{410}$ ) were removed. The use of a 5-times higher dose of PAC increased pollutant removal: the efficiency of color removal was 1.5 times higher, that of DOC removal was 4.5 times higher and that of COD removal was 2.7 times higher. The adsorption was efficient also for removal of humic substances: the efficiency of sorption alone was 25.5 and $45.0 \%$ for the doses of PAC, which, when compared to the lower reduction of humic substances in direct fine-UF (20.2\%), indicates that humic substances are removed by PAC adsorption alone with a higher efficiency than by UF alone. The removal of IC with fine-UF alone was $20.7 \%$, and the use of PAC increased IC rejection to 33.8 and $44.3 \%$, depending on the dose. Because, during adsorption, IC is not removed, this increase in rejection of IC resulted from the fact that PAC blocked membrane pores to some extent, which decreased the membrane cutoff and allowed the retention of IC.

Some amount of organic substances was still reported in the solution after PAC adsorption. On the membrane, the removal of COD, DOC, $\mathrm{UV}_{254}, \mathrm{UV}_{410}$ and IC was observed with the efficiencies higher than by the fine-UF alone. This was attributed to size exclusion and indicates that organic pollutants are first retained in the sorption sites of PAC, 
and then, they are separated by the membrane. In addition, colloidal substances retained on the membrane may adsorb other organic substances, which increase the pollutant rejection (Andrade et al. 2014). The lower efficiency of humic substances $\left(\mathrm{UV}_{254}\right)$ removal by fine-UF in series $3(1 \mathrm{~g} / \mathrm{L}$ PAC-fine-UF) than in series $2(0.2 \mathrm{~g} / \mathrm{L}$ PAC-fine-UF) is a consequence of the high efficiency of humic substances adsorption at the higher PAC dose.

The mass balance calculated with the measured loadings of pollutants in the feed, permeate and retentate indicated that, independently of the operational conditions, 34-40\% of COD and $30-31 \%$ of DOC were adsorbed on the surface of a membrane, and as a consequence, the concentrations in the retentate were not as large as expected. In addition to size exclusion, adsorption is considered a mechanism of organic compound rejection, in which particles are caught inside the structure of the membrane (Guo et al. 2009).

Although the use of a higher dose of PAC gave better results in the adsorption of organic pollutants, the results for total pollutant removal in the integrated system were similar at both PAC doses (COD 86.0-86.7\%, DOC 88.1-92.5\%, $\mathrm{UV}_{254}$ 51.7-51.9\%, UV ${ }_{410}$ 93.5-94.3\%, Table 2). Mozia et al. (2005) also showed that a PAC-UF effectively removed organic substances with low or high MWs. According to the authors, the PAC present in the feed to this system adsorbed low-MW organic substances that UF would not remove alone. However, it should be emphasized that Mozia et al. (2005) used a solution of phenol and humic acids, not landfill leachate.

In this study, the use of membranes in the second stage of the system limited the effect of the different PAC doses. Therefore, not only the efficiency of pollutant removal but also the hydraulic capacity of the membranes has to be taken into consideration in the selection of the adsorbent dose in the integrated systems.

\section{Hydraulic parameters of membranes}

In this study, along with examination of pollutant removal, the major hydraulic parameters for membrane filtration were determined. In general, membrane filtration is considered as not satisfactory as a single process in leachate treatment because of membrane fouling (Mariam and Nghiem 2010). Fouling of membranes by humic substances limits the effectiveness of UF and MF and can be caused by formation of the filtration cake and accumulation of solutes on the surface or in the pores of the membrane (Aoustin et al. 2001; Mozia et al. 2005). However, in the present study, ceramic membranes with good fouling resistance due to highly hydrophilic surface were used. In direct fine-UF of leachate, the initial $J_{\mathrm{V}}$ was $170 \mathrm{~L} /\left(\mathrm{m}^{2} \mathrm{~h}\right)$ (Fig. 3a); this decreased rapidly at the beginning of filtration and then more slowly. In all the experimental series, the TMP was not increased. This
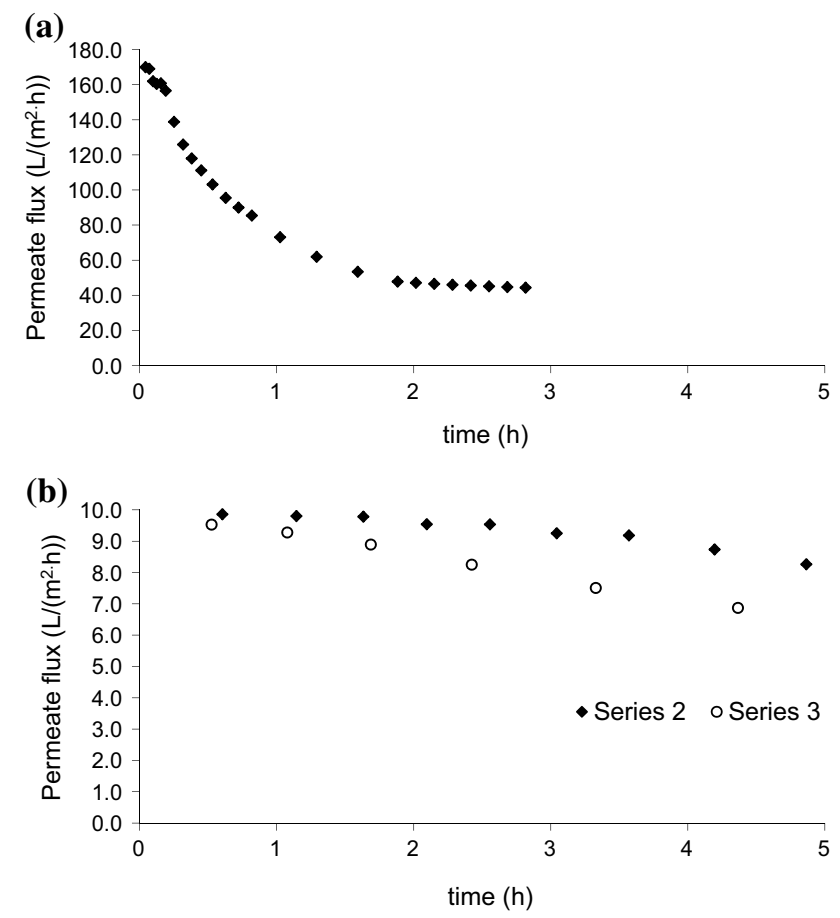

Fig. 3 Changes in permeate flux $\left(J_{\mathrm{V}}\right)$ with time; a series 1 , b series 2 and 3

Table 3 Hydraulic parameters of membrane filtration

\begin{tabular}{llllll}
\hline Series & $\begin{array}{l}\text { Permeate flux } \\
\left(\mathrm{L} /\left(\mathrm{m}^{2} \mathrm{~h}\right)\right)\end{array}$ & $Y(\%)$ & $V C F(-)$ & $R_{\mathrm{m}}((\mathrm{MPa} \mathrm{s}) / \mathrm{m})$ & $\alpha(-)$ \\
\hline 1 & 96.1 & 60 & 2.47 & 29,968 & 0.15 \\
2 & 9.3 & 45 & 1.82 & 309,677 & 0.01 \\
3 & 8.4 & 25 & 1.33 & 342,857 & 0.01 \\
\hline
\end{tabular}

is why the $J_{\mathrm{V}}$ decreased progressively and then started to be stable up to the stop of the permeate flow. (In Fig. 3, the whole period of the permeate flow is shown.) These decreases in permeate flux during filtration in all the experimental series indicated the fouling of the membrane pores by substances present in the feed. When leachate was first exposed to PAC at doses of 0.2 and $1.0 \mathrm{~g} / \mathrm{L}$, the initial $J_{\mathrm{V}}$ lowered to 9.9 and $9.5 \mathrm{~L} /\left(\mathrm{m}^{2} \mathrm{~h}\right)$, respectively. The average value of $J_{\mathrm{V}}$ throughout the entire permeation test was $96.1 \mathrm{~L} /$ $\left(\mathrm{m}^{2} \mathrm{~h}\right)$ in direct fine-UF; this value dropped to 9.3 and 8.4 $\mathrm{L} /\left(\mathrm{m}^{2} \mathrm{~h}\right)$ after PAC adsorption (Table 3$)$. The other results were obtained by Renou et al. (2009) on UF (cutoffs of the membranes between 50 and $1 \mathrm{kDa}$ ) for the raw leachate filtration. The membrane productivities were not satisfactory $\left(55-60 \mathrm{~L} /\left(\mathrm{m}^{2} \mathrm{~h}\right)\right)$, but were improved by pre-treatment with lime addition. The lime allowed carbonates to precipitate and eliminated humic acids, which cause membrane fouling, by co-precipitation. 
In general, adsorption in the first stage of technological systems is used to improve the removal of dissolved organic matter and to increase membrane capacity. PAC, which adsorbs organic molecules, can be used as a "flux enhancer," thus improving the filterability (Damayanti et al. 2011). However, in the present study, the presence of PAC particles in the feed caused membrane blocking. This is in agreement with a study by Akram and Stuckey (2008), who stated that an excess of adsorbent can increase membrane fouling. In the present study, total removal of pollutants in the integrated system was similar at either PAC dose; however, the dose of PAC of $1 \mathrm{~g} / \mathrm{L}$ decreased the permeate flux more than the dose of $0.2 \mathrm{~g} / \mathrm{L}$. This indicates that PAC itself was the main reason of membrane fouling. Hence, although a higher PAC dose resulted in a higher amount of pollutant adsorbed, the use of this higher dose is technologically unjustified. All the more, the significant differences in the pollutant removal efficiencies in adsorption with lower and higher PAC doses do not translate into the removal efficiency in the whole system.

Lin et al. (1999), using a solution of humic acids, showed that PAC of an approximately $730 \mathrm{~m}^{2} / \mathrm{g}$ surface area adsorbed humic substances in the middle MWs and was ineffective in removing substances with MW fractions $<300 \mathrm{Da}$ or $>17,000 \mathrm{Da}$. On this basis, they stated that membrane fouling was caused by molecules with MWs either $<300 \mathrm{Da}$ or $>17,000 \mathrm{Da}$. Because these molecules are not removed by PAC, they are present in the feed solution that enters the membrane system and appear to affect permeate flux. In the present study, however, fouling was not caused by humic substances but by the particles of PAC. This can be deduced from the fact that permeate flux was $96.1 \mathrm{~L} /\left(\mathrm{m}^{2} \mathrm{~h}\right)$ during fine-UF alone and about 10 times less when PAC adsorption was included in the system.

The main factor that affects fouling is the proportion between size of the pores and the particle size (Lim and Bai 2003). In this study, the PAC particles were bigger than the membrane pores. In general, when larger particles are retained by a membrane with smaller pore size, the particles are retained on its surface and a filtration cake is formed more quickly. However, these retained particles should be removed by the shearing forces created by cross-flow filtration, which was used in the present experiment. On the other hand, better rejection of IC ( $44.3 \%$ in series 3 vs. $33.8 \%$ in series 2) was obtained at the higher dose of PAC. These inorganic pollutants are not sorbed by PAC; instead, these pollutants are retained when the effective diameter of the membrane pores is decreased by pore blocking caused by PAC particles with adsorbed organic matter (LaPara et al. 2006). Without this membrane blocking, UF cannot reduce mineral pollution (Renou et al. 2009).

In this study, another sign of fouling was a $J_{\mathrm{V}}$ value that was many times lower than the value of $J_{\mathrm{W}}$ (Table 3). An $\alpha$ value below 1 shows membrane blocking by organic substances that accumulate on the membrane surface and in its pores. This was reported in each series. An $\alpha$ value about zero indicates quick fouling of the membrane. This was observed in series 2 and 3, where the $\alpha$ value was an order of magnitude lower than in series 1 . In addition, the membrane resistance was much higher during the filtration of leachate after the adsorption (Table 3).

To conclude, high consumption of the adsorbent is the major drawback of adsorption application for the treatment of landfill leachate; therefore, the proper determination of adsorbent dose range, in which the efficiency of the organic compound removal is increased the most by a unit dose of the adsorbent, is crucial in this technology. The most important result of this study is that a dose of activated carbon can be very low for achieving high efficiency of COD and DOC removal when using two-stage systems. This is because the differences in the pollutant concentrations in the effluents from adsorption are overcome in membrane filtration. This phenomenon results from the fact that effective membrane pore size during filtration is getting lower than nominal pore size, which gives high removal efficiency of low-sized particles from leachate.

Effective removal of organic pollutants from the leachate in the systems that include membrane filtration is connected with the production of retentate that should be further disposed. According to Renou et al. (2008), retentate can be transported to the wastewater treatment plants, solidified or injected back to the landfill. However, it should be taken into account that retentate consists of high amount of valuable humic acids that can be recovered and used. Although this requires further studies, it is of great potential for the strategy of leachate remediation and management.

\section{Conclusion}

The study tested the PAC adsorption-fine-UF system for the removal of organic compounds from stabilized municipal landfill leachate. Although fine-UF alone did not effectively remove organics, combining adsorption on Norit SX2 with fine-UF was more effective. The efficiency of organics removal by adsorption differed at the two doses of Norit SX2 that were tested (12.9 and 34.5\% of COD, 12.2 and $54.7 \%$ of DOC, at 0.2 and $1 \mathrm{~g} / \mathrm{L}$, respectively), but quality of the membrane permeate did not differ substantially at these two doses (COD 209-220 mg/L, DOC 32-53 mg/L). Thus, the use of fine-UF in the second stage of the system overcame the effect of the different PAC doses. Although the use of two-stage systems resulted in better quality of the final effluent than fine-UF alone, hydraulic parameters were worsened. The capacity of the membrane was $96.1 \mathrm{~L} /$ $\left(\mathrm{m}^{2} \mathrm{~h}\right)$ in direct fine-UF, but this dropped to 9.3 and $8.4 \mathrm{~L} /$ 
$\left(\mathrm{m}^{2} \mathrm{~h}\right)$ after adsorption with Norit SX2 at doses of 0.2 and $1.0 \mathrm{~g} / \mathrm{L}$, respectively.

Acknowledgements The study was supported by a Ministry of Science and Higher Education in Poland (Statutory Research, 18.610.006-300).

Open Access This article is distributed under the terms of the Creative Commons Attribution 4.0 International License (http://creativeco mmons.org/licenses/by/4.0/), which permits unrestricted use, distribution, and reproduction in any medium, provided you give appropriate credit to the original author(s) and the source, provide a link to the Creative Commons license, and indicate if changes were made.

\section{References}

Akram A, Stuckey DC (2008) Flux and performance improvement in a submerged anaerobic membrane bioreactor (SAMBR) using powdered activated carbon (PAC). Process Biochem 43:93-102

Andrade LH, Mendes FDS, Espindola JC, Amaral MCS (2014) Nanofiltration as tertiary treatment for the reuse of dairy wastewater treated by membrane bioreactor. Sep Purif Technol 126:21-29

Aoustin E, Schäfer AI, Fane AG, Waite TD (2001) Ultrafiltration of natural organic matter. Sep Purif Technol 22-23:63-78

Assou M, El Fels L, El Asli A, Fakidi H, Souabi S, Hafidi M (2016) Landfill leachate treatment by a coagulation-flocculation process: effect of the introduction order of the reagents. Desalin Water Treat 57:21817-21826

Bernardo-Bricker AR, Sigh SK, Trovo AG, Tang WZ, Tachiev G (2014) Biodegradability enhancement of mature landfill leachate using Fenton process under different COD loading factors. Environ Process 1:207-219

Bohdziewicz J, Bodzek M, Gorska J (2001) Application of pressuredriven membrane techniques to biological treatment of landfill leachate. Process Biochem 36:641-646

Campinas M, Rosa M (2010) Assessing PAC contribution to the NOM fouling control in PAC/UF system. Water Res 44:1636-1644

Chaouki Z, Khalil F, Ijjaali M, Valdés H, Rafqah S, Sarakha M, Zaitan $\mathrm{H}$ (2017) Use of combination of coagulation and adsorption process for the landfill leachate treatment from Casablanca city. Desalin Water Treat 83:262-271

Chaudhari LB, Murthy ZVP (2010) Treatment of landfill leachates by nanofiltration. J Environ Manage 9:1209-1217

Chiang YP, Liang YY, Chang CN, Chao AC (2006) Differentiating ozone direct and indirect reactions on decomposition of humic substances. Chemosphere 65:2395-2400

Cortez S, Teixeira P, Oliveira R, Mota M (2010a) Fenton's oxidation as post-treatment of a mature municipal landfill leachate. Int J Civil Environ Eng 2:40-43

Cortez S, Teixeira P, Oliveira R, Mota M (2010b) Ozonation as a polishing treatment of mature landfill leachate. J Hazard Mater 182:730-734

Damayanti A, Ujang Z, Salim MR (2011) The influence of PAC, zeolite, and Moringa oleifera as biofouling reducer (BFR) on hybrid membrane bioreactor of palm oil mill effluent (POME). Bioresour Technol 102:4341-4346

Dolar D, Košutić K, Strmecky T (2016) Hybrid processes for treatment of landfill leachate: coagulation/UF/NF-RO and adsorption/UF/ NF-RO. Sep Purif Technol 168:39-46
Gandhimathi R, Durai NJ, Nidheesh PV, Ramesh ST, Kanmani S (2013) Use of combined coagulation-adsorption process as pretreatment of landfill leachate. Iran J Environ Health Sci Eng 10(1): 24

Greenberg AE, Clesceri LS, Eaton AD (eds) (1992) Standard methods for the examination of water and wastewater, 18th edn. APHAAWWA-WEEF, Washington DC

Guo X, Zhang Z, Fang L, Su L (2009) Study on ultrafiltration for surface water by a polyvinylchloride hollow fiber membrane. Desalination 238:183-191

Hermanowicz W, Dożańska W, Dojlido J, Koziorowski B (1999) Fizyczno-chemiczne badanie wody i ścieków. Arkady, Warszawa (in Polish)

Kamaruddin MA, Abdullah MMA, Yusoff MS, Alrozi R, Neculai O (2017) Coagulation-flocculation process in landfill leachate treatment: focus on coagulants and coagulants aid. IOP conference series: materials science and engineering, vol 209, p 012083

Kulikowska D, Bernat K, Parszuto K, Sułek P (2016) Efficiency and kinetics of organics removal from landfill leachate by adsorption onto powdered and granular activated carbon. Desalin Water Treat $57: 4458-4468$

LaPara TM, Klatt CG, Chen R (2006) Adaptations in bacterial catabolic enzyme activity and community structure in membranecoupled bioreactors fed simple synthetic wastewater. J Biotechnol 121:368-380

Lee AH, Nikraz H, Hung YT (2010) Influence of waste age on landfill leachate quality. Int J Environ Sci Dev 1:347-350

Leszczyński J, Tałałaj I, Walery M, Biedka P (2016) Landfill leachate pretreatment by ozonation. Inż Ekol 48:143-146 (in Polish)

Lim AL, Bai R (2003) Membrane fouling and cleaning in microfiltration of activated sludge wastewater. J Membr Sci 216:279-290

Lin CF, Huang YJ, Hao OJ (1999) Ultrafiltration processes for removing humic substances: effect of molecular weight fractions and PAC treatment. Water Res 33:1252-1264

Mariam T, Nghiem LD (2010) Landfill leachate treatment using hybrid coagulation nanofiltration processes. Desalination 250:677-681

Meier J, Melin T, Eilers LH (2002) Nanofiltration and adsorption on powdered adsorbent as process combination for the treatment waste water of severely contaminated. Desalination 146:361-366

Mozia S, Tomaszewska M, Morawski AW (2005) Studies on the effect of humic acids and phenol on adsorption-ultrafiltration process performance. Water Res 39:501-509

Renou S, Givaudan JG, Poulain S, Dirassouyan F, Moulin P (2008) Landfill leachate treatment: review and opportunity. J Hazard Mater 150:468-493

Renou S, Poulain S, Givaudan JG, Moulin P (2009) Amelioration of ultrafiltration process by lime treatment: case of landfill leachate. Desalination 249:72-82

Rivas FJ, Beltrán FJ, Gimeno O, Frades J, Carvalho F (2006) Adsorption of landfill leachates onto activated carbon. Equilibrium and kinetics. J Hazard Mater 131:170-178

Sanjay M, Amit D, Mukherjee SN (2013) Applications of adsorption process for treatment of landfill leachate. J Environ Res Dev $8: 365-370$

Sivan A, Latha P (2013) Treatment of mature landfill leachate from Vilappilsala by combination chemical and biological processes. Int J Innov Res Sci Eng Technol 2:4405-4414

Zhao P, Takizawa S, Katayama H, Ohgaki S (2005) Factors causing PAC cake fouling in PAC-MF (powdered activated carbon-microfiltration) water treatment systems. Water Sci Technol 51:231-240 